\title{
石油タンク底水を用いた腐食再現試験の
} 次世代シーケンサによる微生物群集構造解析 *

若井 暁 $^{* *}$ ，藤井創太郎 $* * *$ ，政成美沙 ${ }^{* * *}$ ，宮永一彦 ${ }^{\dagger}$, 丹治保典 ${ }^{\dagger}$, 三本木至宏 $* * *$

** 神戸大学 自然科学系先端融合研究環

*** 広島大学大学院生物圈科学研究科

† 東京工業大学大学院 生命理工学研究科

\section{Corrosion Test Using Bottom Water from Oil-storage Tank and Microbial Community Analysis by Next Generation Sequencer*}

\author{
Satoshi Wakai**, Sotaro Fujii***, Misa Masanari***, Kazuhiko Miyanaga $^{\dagger}$, \\ Yasunori Tanji ${ }^{\dagger}$ and Yoshihiro Sambongi*** \\ ** Organization of Advanced Science and Technology, Kobe University \\ *** Graduate School of Biosphere Science, Hiroshima University \\ ${ }^{\dagger}$ Department of Bioengineering, Tokyo Institute of Technology
}

\begin{abstract}
Involvement of microorganisms to corrosion refers to microbiological influenced corrosion (MIC). We have previously succeeded a lab-scale corrosion test using bottom water from oil-storage tanks and shown microbial community change after the corrosion by a denaturing gradient gel electrophoresis analysis. However, those community structures have not yet been correlated to the accelerated corrosion. Therefore, we further conducted analysis of microbial community for by pyrosequencing using a next-generation sequencer. In the corrosion sample, an acetic acid bacterium Acetobacterium sp. and a sulfate-reducing bacterium Desulfovibrio sp. were enriched. In contrast, only Desulfovibrio sp. bacterium was enriched in the non-corroded culture, and Acetobacterium sp. bacterium was not observed. These results indicate that the Acetobacterium sp. bacterium may involve in the accelerated corrosion. This is first report of the corrosion by the Acetobacterium sp. bacterium. The combination of a lab-scale corrosion test and microbial community analysis by pyrosequencing would be useful to correlate between corrosion behavior and microbial community change. In future, such investigation would contribute to the understanding for the microbiologically influenced corrosion.
\end{abstract}

Key words : microbiologically influenced corrosion, oil-storage tank, microbial community, corrosion test, acetic acid bacterium, next-generation sequencer

1. 緒

\section{$\overline{\overline{⿳ 亠 二 口}}$}

微生物が金属腐食に関与することを微生物腐食とい う。この現象は古くから知られているが，単独で強い腐 食能を示す微生物が分離されることは極めて稀である. 一方で，近年，国内外の研究者によって，新規の鉄腐食 性微生物が分離されている ${ }^{1)-7)}$. 例えば, 国内の石油夕 ンクから鉄腐食性メタン生成菌が分離されている ${ }^{2), 3)}$. この鉄腐食性メタン生成菌は, ある種の硫酸塩還元細菌 (SRB) と共存することでさらに激しい腐食を誘導するこ とが示されている ${ }^{8)}$. 単独あるいは二種の微生物での腐 食現象に関する知見が少しずつ得られているが，環境中 には多様な微生物が存在し, その中で微生物腐食は進行 している，そのような複雑系での腐食についての腐食の 進行と微生物群集構造の変化の対応付けはできていな い.

* 材料と環境 2015(東京, 2015 年)で発表

** × 657-8501 神戸市灘区六甲台町 1-1(1-1, Rokkodai, Nada, Kobe, 657-8501 Japan)

*** 7 739-8528 東広島市鏡山 1-4-4 (1-4-4, Kagamiyama, HigashiHiroshima, 739-8528 Japan)

T 226-8501 横浜市緑区長津田町 4259 J2-15(4259 J2-15 Nagatsutacho, Midori-ku, Yokohama, 226-8501 Japan)
ある一時点での静的な微生物群集構造を明らかにした だけでは, 腐食発生のリスクを評価することはできない. 実際に腐食が進行するときの微生物群集の変動やそれに 対応した腐食速度の変化といった知見が必要となる。そ こで我々はまず, 石油夕ンクの底部に溜まっている水(夕 ンク底水)を分析し, 特殊な微生物群集構造が形成され ていることを明らかにしだ'. 次に, タンク底水を用い て研究室レベルで培養し, 固体の鉄から鉄イオンが溶出 するかどうか調べた。その結果，鉄イオンの溶出量が無 生物的なものよりも有意に大きくなる条件を見出した. これを我々は，微生物による腐食の誘導と考えている. このように腐食が誘導された腐食試験液では, 元の夕ン ク底水や他の条件で培養して得た試験液と比べて明らか に異なる微生物群集構造が形成されていることを変性剂 濃度勾配ゲル電気泳動 (DGGE) 解析により明らかにし た ${ }^{10)}$.

腐食に限ったことではないが，微生物群集構造の解析 手法は次世代シーケンサの登場により劇的に向上し，環 境中の微生物の全情報を網羅するほどの解析が可能とな ってきた。従来法では，16S rRNA 遺伝子を標的とした クローンライブラリー法や DGGE 解析法などが行われ ていた.クローンライブラリー法は個々の遺伝子をクロ ーン化する必要があり, 網羅的に微生物種を調べるため には多大な時間と労力を要する. DGGE 解析法は, 電気 
泳動パターンとして複数のサンプルの微生物群集構造を 比較解析することに優れているが，その微生物種を調べ るためには, 電気泳動後のゲルから DNA を抽出して塩 基配列を決定する必要がある，そのため，同様に多大な 時間と労力を要する。一方で, 次世代シーケンサは, ク ローンライブラリー法と DGGE 解析法の両方のメリッ トを備えており, 複数のサンプル中の微生物種を網羅的 に調べることが可能である.

本研究では，これまでに我々がタンク底水を用いて行 った培養・腐食試験で得られた試験液に対して初めて次 世代シーケンサを用いて微生物群集構造を解析し, 腐食 と微生物群集構造の詳細な対応付けを試みた。

\section{2. 方法}

\section{1 実験に使用した試料の由来}

タンク底水と培養および腐食試験で得られた試験液お よびそれらから抽出した DNA は, 以前の研究10)で得ら れたものと同じである. タンク底水は, 九州に設置され ている石油タンク 3 基(KTD1, KTD2, および KTD3)か ら回収したものである。これらのタンク底水を用いて, 夕ンク底水のみ, あるいは, 夕ンク底水に模擬人工海水 培地 ${ }^{3)}$ をべースとした無機塩を添加して嫌気的に 26 週培 養したものを培養試験液，同条件で鉄ホイル (純度 99.9 $\%$ 以上， $10 \times 10 \times 0.1 \mathrm{~mm})$ を加えたものを腐食試験液と 呼ぶ。今回使用した培養・腐食試験液の情報を Table 1 にまとめた。

\section{2 腐食試験液 KTD1-M-Fe の継代培養試験}

腐食試験液 KTD1-M-Fe 中に存在する腐食能を持った 微生物群集を人工的な培地で継承し, 腐食能を維持でき るかどうか検討するために, 以下の継代培養試験を行っ た. 新鮮な模擬人工海水培地 ${ }^{3} 20 \mathrm{~mL}$ を $\mathrm{N}_{2}: \mathrm{CO}_{2}(80$ : 20)でガス置換した $50 \mathrm{~mL}$ 容嫌気瓶中に調製し，鉄ホイ ルを一枚投入して, KTD1-M-Fe の試験液 $1 \mathrm{~mL}$ を植菌し た. $30^{\circ} \mathrm{C} て ゙ ~ 4$ 週培養した後, 溶出した鉄を定量するため に, $100 \mu \mathrm{L}$ の試験液を採取した。ここに等量の $6 \mathrm{M}$ $\mathrm{HCl}$ を添加して不溶鉄を溶解し，2倍量の $1 \mathrm{M}$ L-Ascorbic acid を添加して三価鉄を二価鉄へと還元した. この還元試料に含まれる鉄量を $o$-phenanthroline法 ${ }^{11)} に$ よって測定した。

Table 1 Information of cultivation samples used in this study.

\begin{tabular}{lcccc}
\hline Name & $\begin{array}{c}\text { Bottom } \\
\text { water }\end{array}$ & Iron foil a & $\begin{array}{c}\text { Inorganic } \\
\text { salts }\end{array}$ & Corrosion \\
\hline KTD1-NC & KTD1 & - & - & N/A $^{\mathrm{b}}$ \\
KTD1-M-NC & KTD1 & - & + & N/A \\
KTD1-Fe & KTD1 & + & - & $\begin{array}{c}\text { Slow } \\
\text { dissolution } \\
\text { Accelerated } \\
\text { dissolution }\end{array}$ \\
KTD1-M-Fe & KTD1 & + & + & $\begin{array}{c}\text { Slow } \\
\text { dissolution }\end{array}$ \\
\hline KTD2-M-Fe & KTD2 & + & + & $\begin{array}{c}\text { Slow } \\
\text { dissolution }\end{array}$ \\
\hline KTD3-M-Fe & KTD3 & + & + & + \\
\hline
\end{tabular}

a: +, presence; -, absence

b: N/A means "not applicable" because of absence of iron foil.
2.3 次世代シーケンサを用いた 16S rRNA 遺伝子解 析

継代培養液 (4 週培養)を $0.22 \mu \mathrm{m}$ のメンブレンフィル ター(ADVANTEC) でろ過し, 捕集した微生物から RNA 添加 DNA 抽出法 ${ }^{9}$ により DNA を抽出した。 タンク底水 および培養・腐食試験液 (26 週培養)からの DNA は以前 に回収したもの ${ }^{10)}$ を使用した。抽出したDNAを鋳型に して, 細菌の $16 \mathrm{~S}$ rRNA 遺伝子を標的とした Forward プ ライマー (5’-CCATCTCATCCCTGCGTGTCTCCGACTCAG $\left(\mathrm{X}_{10}\right)$ AGAGTTTGATC (A/C)TGGCTCAG-3’) おょび Reverse プライマー(5-CCTATCCCCTGTGTGCCTTGGCAGTCTCAGG (A/T) ATTACCGCGGC (G/T) GCTG-3’ ) を用いたPCR (ポリメラーゼ連鎖反応)により遺伝子断片 (約 500 塩基 対)を増幅した.このとき，プライマーに任意の 10 塩基 から成るタグ $\left(\mathrm{X}_{10}\right)$ を付加することで各サンプルの識別が できる状態にしておき，各増幅断片のモル比を揃えてリ ーディングサンプルとした。これを次世代シーケンサ (GS FLX+ system, Roche)により解析することで各リ ードの塩基配列を取得した.

取得した配列の解析後処理は QIIME パイプライン ${ }^{12)}$ を用い, タグに対応した配列の整理，プライマー配列の 除去，および OTU (operational taxonomic unit)としての クラスタリングを行った. OTUのクラスタリングは, 属レベルの分類に相当する $97 \%$ 以上の相同性があるもの とした。

\section{3. 結果および考察}

\section{1 タンク底水中の微生物群集}

異なるタンクから回収したタンク底水中の微生物群集 における細菌の OTUの数は，KTD1 で 27 OTUs，KTD2 で 11 OTUs, KTD3で 30 OTUs となった. OTUの数が 多いほど多様性が高い。すなわち, 三者の比較から, KTD1 と KTD3 は多様性が高く, KTD2 は低いというこ とになる。

次に, 微生物群集構造の構成を生物分類体系の門レベ ルで Fig. 1 に示した.この内, Proteobacteria は分類群が 巨大であるため綱 レベル(Alphaproteobacteria, Betaproteobacteria, Gammaproteobacteria, Deltaproteobacteria, Epsilonproteobacteria) で分類した. KTD1 は多様性が高 いとはいえ, Alphaproteobacteria 綱細菌 (35\%) と Chlorobi 門細菌 $(20 \%)$ が半数以上を占めていた (Fig. 1A).KTD2 では, 50\% が Alphaproteobacteria 綱 細 菌, 49\%が Betaproteobacteria 綱細菌となっていた (Fig. 1B). KTD3 では, 未培養細菌群から構成される候補門の細菌 である TM7 が 28\%, Betaproteobacteria 綱細菌が 19\%, Deltaproteobacteria 綱細菌が16\%であった (Fig. 1C). KTD3 で最も多いTM7 門細菌は，これまでに培養に成 功していない未分離菌であり, 本菌が夕ンク底水中に集 積していることは微生物学的な観点からも興味深い。ま た, KTD1 と KTD3 の多様性は見かけ上高いが，それら の微生物の構成は大きく異なっている.

微生物腐食への関係が危惧される細菌として, SRB が, KTD1 と KTD3で，それぞれ 1.5\% (Firmicutes 門と Deltaproteobacteria 綱の一部) および $1.3 \%$ (Firmicutes 門 とDeltaproteobacteria 綱の一部)検出された。 これら二つ 
A
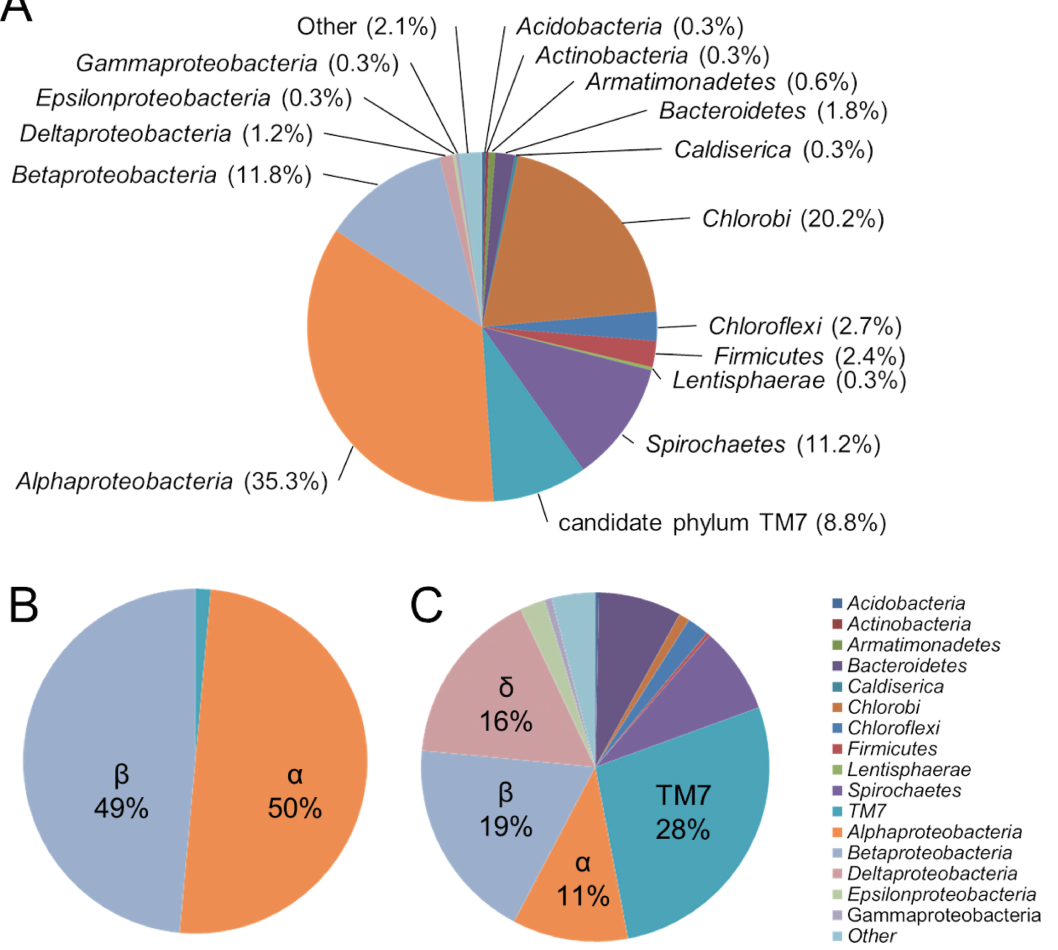

Fig. 1 Compositions of microbial communities in the bottom water from oil-storage tanks. Pie charts indicate relative abundance of each phylum (only Proteobacteria is indicated by Class levels): A, KTD1; B, KTD2; and C, KTD3. Each chart color indicates each phylum or class. $\alpha$, class Alphaproteobacteria; $\beta$, class Betaproteobacteria; $\delta$, class Deltaproteobacteria; and TM7, candidate phylum TM7.

のタンク底水中には $3 \sim 4 \times 10^{7}$ cells $/ \mathrm{mL}$ の微生物細胞が観察されており ${ }^{10)}$, ど ちらのタンクにも約 $10^{5}$ cells $/ \mathrm{mL}$ の濃 度で SRB が存在することとなる。こ れは, タンク底水環境中での微生物腐 食発生のリスクとして, SRBの存在に 注意が必要であることを示唆してい る. 一方で, 以前の研究により KTD1 では加速的な腐食が誘導されるが ${ }^{10)}$, KTD3 では腐食が誘導されないことが 分かっている.この KTD1の腐食前後 の微生物群集を詳細に検討すること で, 腐食に寄与している微生物種の推 定が可能となるだろう。

\section{2 培養・腐食試験の試験液中の 微生物群集}

微生物腐食発生のリスクの一つであ るSRBが検出されており，実際に加 速的な鉄溶出によって示される腐食誘 導を起こした KTD1 由来の培養・腐食 試験液について同様に微生物群集構造 解析を行った。

\subsection{1 鉄ホイル非存在下での培養 試験}

最初に, 採水した試料の保管状態や 無機塩の混入が微生物群集構造に与え
る影響を知るために，ガス置換して静 置した場合とさらに無機塩 (模擬人工 海水培地)を添加して静置した腐食試 験液の微生物群集構造を解析した.

タンク底水 KTD1 をガス置換して静 置しただけの場合(KTD1-NC), Alphaproteobacteria 綱細菌が全体の 35 \%から 66\%に増加し, Chlorobi 門細菌 が 20\%から 3\%まで減少していた (Fig. 2A).この場合は，栄養塩が不足した 環境であることから，他の細菌が死滅 して減少し, 理由は不明であるが Alphaproteobacteria 綱細菌が多く生き 残ったことで見かけ上増加したと考え られる。一方, 底水に無機塩を添加し た場合 (KTD1-M-NC), Betaproteobacteria 綱細菌が $60 \%$ にまで増加していた (Fig. 2B).これは, 有機物のような栄 養塩の添加がなくとも, 生育に必要な 微量元素の不足によって活動が停止し ていた微生物が, 無機塩の補充によっ て増加することを示唆している.

これらの結果は, 微生物腐食の診断 を目的として環境試料の微生物群集構 造を解析する際に，その保管状態が群 集構造に影響を与えることを示してい る.したがって, 微生物群集構造の人 為的な変動を排除するためには，腐食 が生じた現場の微生物群集構造を速や かに解析する必要がある.
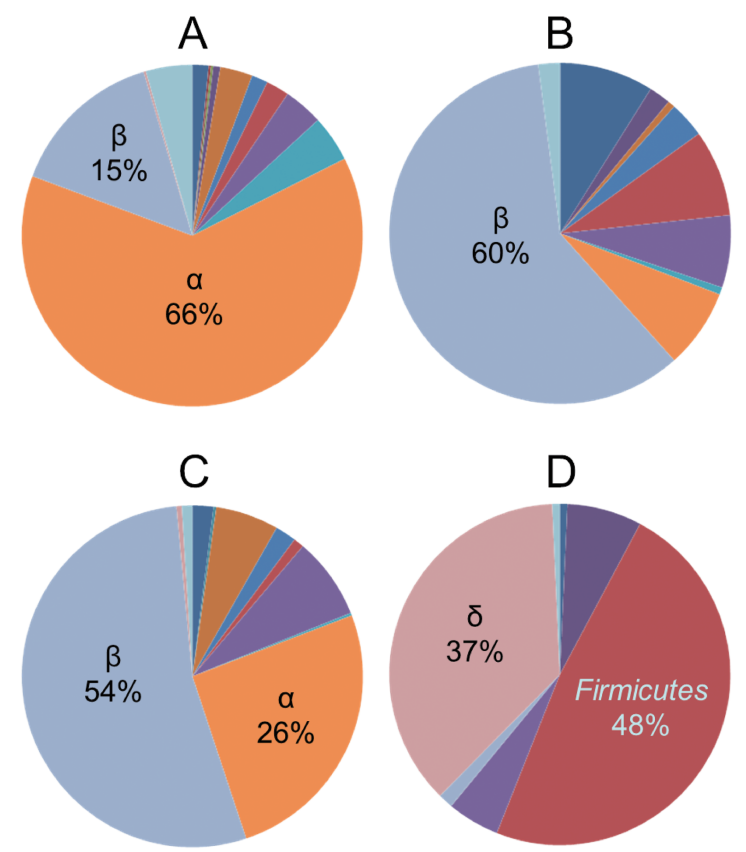

- Acidobacteria

- Actinobacteria - Armatimonadetes - Bacteroidetes - Caldiserica - Chlorobi Chloroflexi - Firmicutes - Lentisphaerae - Spirochaetes - TM7 - Alphaproteobacteria - Deltaproteobacteria Epsilonproteobacteria - Gammaproteobacteria - Other

Fig. 2 Comparative analysis of microbial communities among samples from lab-scale test using the bottom water from KTD1. Each sample was incubated at $30^{\circ} \mathrm{C}$ for 26 weeks. A: incubation without any additives, B: incubation with inorganic salt medium, C: incubation with iron foil, and D: incubation with inorganic salt medium and iron foil. Each chart color indicates each phylum or class. $\alpha$, class Alphaproteobacteria; $\beta$, class Betaproteobacteria; and $\delta$, class Deltaproteobacteria. 


\subsection{2 鉄ホイル存在下での腐食試験}

次に, このタンク底水 (KTD1) が腐食され得る金属の 表面に接触した場合にどのような群集構造の変動を見せ るのかを調べるために，鉄ホイルを添加して静置培養し た. 底水に鉄ホイルを添加しただけの場合, Betaproteobacteria 綱細菌が 54\%まで増加していた (Fig. 2C). しかし, この腐食試験液では鉄腐食の誘導が起こ っておらず，無機塩や鉄ホイルの投入で増加した Betaproteobacteria 綱細菌は鉄腐食性がないと考えられ る。一方で, 顕著に腐食が誘導された腐食試験液(無機 塩および鉄ホイルの同時添加：KTD1-M-Fe）では, Firmicutes 門細菌が48\%,Deltaproteobacteria 綱細菌が $37 \%$ と顕著に異なる群集構造を示した (Fig. 2D). 著しく 増殖した Firmicutes 門細菌は Acetobacterium 属の酢酸菌 で占められており, Deltaproteobacteria 綱細菌では Desulfovibrio 属のSRBのみで構成されていた.

\subsection{3 腐食サンプルと非腐食サンプルとの比較}

腐食再現試験において KTD1-M-Fe は唯一加速された 鉄溶出を示す“腐食サンプル”であるが，同条件で試験 した KTD2-M-Fe および KTD3-M-Fe では加速された鉄の 溶出は観察されていない. そこで，これらの鉄溶出が加 速されない“非腐食サンプル”についても微生物群集構 造を調べた。

タンク底水 $(\mathrm{KTD} 3)$ に無機塩を添加し，鉄ホイルを投 入した KTD2-M-Feでは，検出限界以下であった Desulfovibrio 属の SRB が，60\%にまで増加していた。ま た同様に別のタンク底水(KTD3)を用いた試験区 KTD3M-Fe においても, 検出限界以下であったDesulfovibrio 属の SRB が 15\%まで増加していたが，加速された鉄溶 出は起きていない。また，Firmicutes 門の細菌が $52 \%$ ま で増加したが, 増加したものはAcetobacterium 属細菌で はなく, Pelotomaculum 属細菌であった。本菌は, 芽胞 を形成する好熱性の従属栄養細菌であり ${ }^{13)}$, その高い生 存率により見かけ上優占化した可能性も考えられる.

以上の結果から, 腐食サンプルと非腐食サンプルの双 方で SRB の増加は共通するが, 腐食サンプルでのみ Acetobacterium 属細菌が増加しており, Acetobacterium 属細菌が加速された鉄の溶出に関与していることが示さ れた。 また，双方で増加しているDesulfovibrio 属の SRB は, 単独では鉄溶出の加速に関与しないことを示唆して いる。

\section{3 鉄腐食性微生物群の継代と群集構造解析}

研究室レベルで腐食を再現しようとする試験では, 環 境水試料から合成培地に植え替えること(継代)で腐食の 再現性が失われることが経験的に知られている，そこで, 腐食能の継承と群集構造の関係を調べるために, 加速的 な溶出を誘導した KTD1-M-Fe 試験液から継代培養を行 い, その腐食能および微生物群集構造の維持・変化を調 べた.

継代した培養物は無菌区の約 8 倍の鉄溶出量を示した (Fig. 3A)。したがって，この継代培養物には，鉄腐食能 が継承されている。次に, 次世代シーケンス解析により 微生物群集構造を調べた. KTD1-M-Fe と比較すると, Desulfovibrio 属細菌が $37 \%$ から $23 \%$ に減少し, Acetobacterium 属細菌が 48\%から 76\%に増加しており, この 2 属の細菌種のみで全構成の $99 \%$ を占めていた (Fig. 3B). すなわち, 若干の組成変化が見られるが, 重要と 思われるDesulfovibrio 属細菌とAcetobacterium 属細菌を 主とする構成は維持されていた。

以上の結果から, KTD1-M-Fe で観察された腐食は, Acetobacterium 属の酢酸菌単独による腐食もしくは, 酢 酸菌と SRBの共存による協調的な腐食と推定できる. Acetobacterium 属細菌は水素を酸化し, 二酸化炭素を還 元することで酢酸を生成することができ ${ }^{14)}$ ，この酢酸を 資化することでDesulfovibrio 属細菌が硫酸還元を行い, 生じた硫化水素によって腐食が進行していると考えられ る。この腐食メカニズムにおいて, Acetobacterium 属細 菌への水素供給メカニズムがまだ不明であるが，近年報 告されている鉄腐食性酢酸菌(6) のように単独で腐食誘導 を行う可能性もある。また, 鉄腐食性メ夕ン生成菌によ る腐食では, 単独で腐食誘導を行わない SRB との共存 による協調的な腐食促進が報告8) されており，同様の関 係が成立しているかもしれない。

\section{4. 結論}

本研究では, 次世代シーケンサを用いて微生物群集構 造を詳細に調べることで, 微生物群集構造の変化と微生 物による金属腐食現象を関連付けることを目指した。従 来の微生物群集構造解析と比較して, 次世代シーケンサ を用いることで, 微生物の構成を定量的に解析すること や存在数の少ないマイナーな微生物群の詳細を明らかに
A

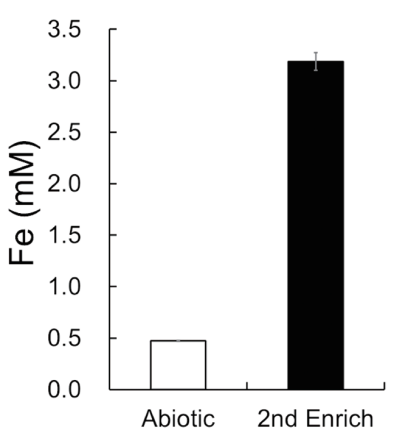

B

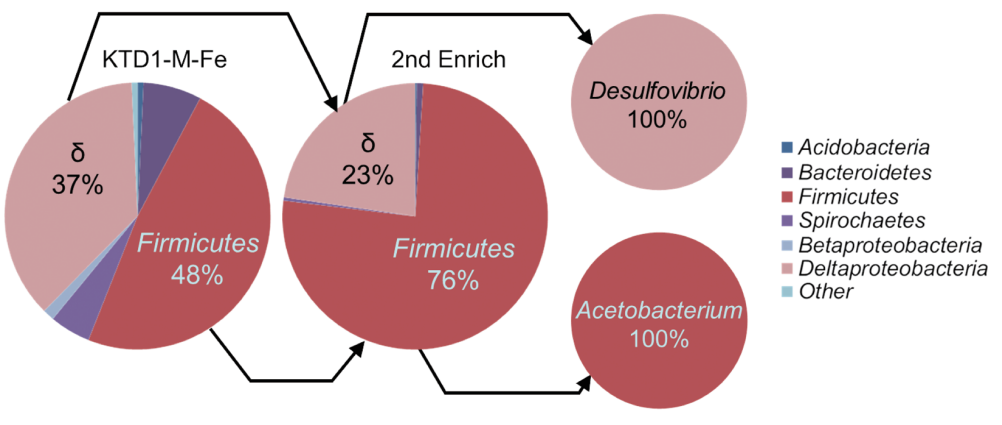

Fig. 3 Corrosion test (A) and microbial community analysis in the $2^{\text {nd }}$ enriched sample by batch cultivation. Corroded Fe dissolved from iron foil was measured after 4 week cultivation. Each chart color indicates each phylum or class. 
することに成功した。また，腐食サンプルと非腐食サン プルの群集構造を比較解析することで, Acetobacterium 属の酢酸菌が腐食に強く関与することを示した. Acetobacterium 属細菌が主要な原因菌として引き起こさ れる腐食例は, これまでに報告がない, 今後, 次世代シ ーケンサを利用した網羅的な試験と培養に依存した腐食 再現試験を組み合わせた試験が普及することによって, 未知の腐食菌の存在を明らかにできる可能性が期待でき る。また，これらのデータが蓄積することによって，腐 食リスク評価の精度が向上すると期待できる.

本研究は, 公益財団法人中国電力技術研究財団の一般 研究助成金により実施された。

\section{参 考 文 献}

1) H. T. Dinh, J. Kuever, M. Mußmann, A. W. Hassel, M. Stratmann and F. Widdel, Nature, 427, 829 (2004).

2) K. Mori, H. Tsurumaru and S. Harayama, J. Biosci. Bioeng., 110, 426 (2010).

3) T. Uchiyama, K. Ito, K. Mori, H. Tsurumaru and S. Harayama, Appl. Environ. Microbiol., 76, 1783 (2010).

4) J. M. McBeth, B. J. Little, R. I. Ray, K. M. Farrar and D. Emerson, Appl. Environ. Microbiol., 77, 1405 (2011).

5) S. Wakai, K. Ito, T. Iino, Y. Tomoe, K. Mori and S.
Harayama, Microb. Ecol., 68, 519 (2014).

6) S. Kato, I. Yumoto and Y. Kamagata, Appl. Environ. Microbiol., 81, 67 (2015).

7) T. Iino, K. Ito, S. Wakai, H. Tsurumaru, M. Ohkuma and S. Harayama, Appl. Environ. Microbiol., 81, 1839 (2015).

8) K. Ito, S. Wakai, H. Tsurumaru, T. Iino, K. Mori, T. Uchiyama, O. Miki and S. Harayama, EUROCORR proceedings, 1063, 1 (2008).

9) S. Wakai, M. Masanari, T. Watanabe and Y. Sambongi, Inspection Eng., 17, 1 (2012).

10) S. Wakai, S. Fujii, M. Masanari, A. Abe and Y. Sambongi, Zairyo-to-Kankyo, 62, 389 (2013).

11) E. B. Sandell, "Colorimetric determination of trace metals". John Willey \& Sons, Inc., New York (1950).

12) J. G. Caporaso, J. Kuczynski, J. Stombaugh, K. Bittinger, F. D. Bushman, E. K. Costello, N. Fierer, A. G. Peña, J. K. Goodrich, J. I. Gordon, G. A. Huttley, S. T. Kelley, D. Knights, J. E. Koenig, R. E. Ley, C. A. Lozupone, D. McDonald, B. D. Muegge, M. Pirrung, J. Reeder, J. R. Sevinsky, P. J. Turnbaugh, W. A. Walters, J. Widmann, T. Yatsunenko, J. Zaneveld and R. Knight, Nature methods, 7, 335 (2010).

13) H. Imachi, Y. Sekiguchi, Y. Kamagata, S. Hanada, A. Ohashi and H. Harada, Int. J. Syst. Evol. Microbiol., 52, 1729 (2002)

14) W. E. Balch, S. Schoberth, R. S. Tanner and R. S. Wolfe, Int. J. System. Bacteriol., 27, 355 (1977).

(Manuscript received June 22, 2015; in final form September 15, 2015)

要旨

微生物が関与する金属の腐食現象を微生物腐食と呼ぶ。これまでに, 石油タンク底水を用いて実験室レ ベルでの腐食再現試験に成功し, DGGE解析によって微生物群集構造の変化が起こっていることを明らか にしてきたが, 群集構造の詳細と腐食現象の関連付けが出来ていなかった。 そこで, 本研究では, 次世代 シーケンサを用いてタンク底水および培養・腐食試験液中の微生物群集構造の詳細を明らかにし, 腐食現 象と微生物群集構造の関連付けを試みた。 タンク底水を用いた群集構造解析では, タンクごとにその群集 構造が大きく異なることを定量的に明らかにした。また, その群集構造が, 置かれる環境条件によって変 化することを明らかにした，加速された鉄の溶出を示した試料 KTD1-M-Feでは, Acetobacterium 属酢酸 菌とDesulfovibrio 属硫酸塩還元細菌が集積していた. Desulfovibrio 属硫酸塩還元細菌のみが集積した試料 で腐食が生じていないことから，Acetobacterium 属の酢酸菌が腐食に強く関与することが示された. Acetobacterium 属細菌が主要な原因菌として引き起こされる腐食例は, これまでに報告がない. 以上の結 果から, 培養に依存した腐食再現試験と次世代シーケンサを組み合わせた比較解析は, 腐食現象と微生物 群集構造を関連付けるために有効な手法であると言えるだろう。

キーワード＼cjkstart微生物腐食, 石油タンク, 微生物群集, 腐食再現試験, 酢酸菌, 次世代シーケンサ 